\title{
A Study of Ellipsis in English and Hindi Short Stories
}

\author{
Amitabh Vikram Dwivedi \\ School of Languages \& Literature, Shri Mata Vaishno Devi University, India
}

Copyright (C) 2015 by authors, all rights reserved. Authors agree that this article remains permanently open access under the terms of the Creative Commons Attribution License 4.0 International License

\begin{abstract}
Every language uses elliptical structures, but how frequently nominal, verbal and clasual ellipsis occur in Hindi and English language, is the focus of this study. This paper is an effort to analyze ellipsis in two short stories: a work in Hindi language (a short story by Munshi Premchand), and a work in English language (a short story by Ernest Hemingway). The comparison is supported by the statistical analysis. The goal of this paper is to illustrate the diversity and complexity of ellipsis in two writers' works through language. The paper follows the theoretical functional grammar approach of Halliday and Hasan.
\end{abstract}

Keywords Ellipsis, Hindi \& English Stories, Functional Grammar

\section{Introduction}

The present paper is an effort to analyze ellipsis in two short stories. The study concentrates on the way to go from data to the description rather than on raising question: how ellipsis is learned or acquired? Two literary works which are considered to be the masterpiece in their languages, namely the works of Hemingway in English and Premchand in Hindi has been taken into account in the study. Since adult second language learners tend to focus more on the grammatical structures of the target language, the present study has been undertaken, keeping in view the growing demands of learning English in general, and learning English in Hindi speaking states in India. The translated English text from Hindi will help such learners to compare the structures of both the languages, and they will get to know how and where the structures of noun phrases, verb phrases, and adpositional phrases might occur and become elliptical in two languages.

Ernest Hemingway's Hills Like White Elephants (Stone) [1] and Munshi Premchand's Jaado (trans. Secret) (Premchand) [2] have been studied in this paper. Premchand and Hemingway are the representative writers of their languages. It is said that Premchand's style in the story titled, Secret is in a crisp, staccato, Hemingwayesque dialogue. The paper follows the cohesion and theoretical functional grammar approach of Halliday and Hasan [3], and the goal of this study is to illustrate the diversity and complexity of ellipsis in two works.

The remainder of this paper is organized under the following headings: Ellipsis tells us about the linguistic category recoverable from the context, the heading Hindi and English in India recounts the status of two official languages in India, the heading Hills Like White Elephant and Jaadu summarizes the two stories, under the heading Theoretical foundation a brief account of previous studies conducted in cohesion is presented, in the next section Data and discussion, the data is analysed employing functional grammar approach and it is supported by the content analysis, and finally the heading Conclusion concludes the paper.

\section{Ellipsis}

Ellipsis, a cohesive device, is a universal linguistic phenomenon which is generally employed without any real awareness of how it is structured by the language users. A relation of cohesion is established where the interpretation of some element presupposes, and is dependent on another, so creating a tie and integrating the two elements into a text [4]. The elliptical elements remain redundant in the language and thus it is recoverable from the context. The economy of statement motivates the speakers to employ ellipsis whenever and wherever it is feasible. Ellipsis, unlike reference and substitution, is simply a substitution by zero.

\section{Hindi and English in India}

Hindi belongs to Indo-Aryan family which is a subgroup of Indo-European. The source of modern Hindi is Khariboli and there are many influences of Apabhramsa, Persian and Arabic language on it. During the colonial period with the establishment of British rule in India, English also influenced Hindi. In nineteenth century the Hindi renaissance movement gave a new life to Hindi and it began to draw words from Sanskrit. During the freedom struggle of Inida, M. K. Gandhi advocated for the development of a commonly used language, especially Hindi or Hindustani which would absorb commonly used elements of both Urdu 
and Sanskrit and which resulted in the modern Hindi which is one of the languages taken up for the analysis and description in this paper [5].

Post-independence in 1950, the Article 343 of the Indian Constitution designated Hindi as the official language of the Union, and the Union decided to continue the use of English language for all official purposes for a period of fifteen years. But, after nine years, the Official Language Commission of India extended the use of English, and parliament enacted a law in 1963 bowing to the sentiments of people from the south India [6]. In 1965, India decided not to make Hindi a sole official language, and English became an associate official language. Now there is no national language in India. There are two official languages and many regional languages in the country.

\section{Two Stories: Hills like White Elephant and Jaadu}

The title of the story (The) Hills (Are) Like White Elephants is itself elliptical. There is an omission of an article "the" and auxiliary "are." The story opens with a brief description of the view of the white hills from a train station in Spain. A girl and an American man are waiting for the train to Barcelona and having some beers outside the station.

The girl tells the man that the hills remind her of "white elephants." The man has never seen white elephants but the girl's reply "no, you wouldn't have" irritates him. This starts a little argument between them. The girl sidesteps it by pointing out to man that something has been painted on the beaded curtain that hangs over the doorway of the bar. The painting advertises a drink called Anis del Toro, which they ordered.

Their conversation remains terse and tense, and soon the man starts trying to convince the girl, Jig, to have an abortion, if she wants to. The girl is not convinced that the operation will bring their relationship on track, and their problems will be solved. He tells her that their relationship is fine, but he is worried because of this pregnancy. She agrees for the operation, but she says that she no longer cares about herself. The man says she shouldn't do it for that reason and only does if she wants to.

This situation frustrates the girl and she feels that everything is now lost. The man reassures her that this is not the case, and finally tells her that he would prefer that she have the abortion. She becomes agitated and asks him to stop talking, and threatens him that she will scream if he doesn't stop.

The woman who has been serving them drinks tells them that the train is coming in five minutes, and the man gets up and picks up their luggage over to the train stop. He takes another Anis del Toro., and gets back to Jig, she smiles. He asks her if she "feel [s]" better," and she says "There's nothing wrong with me [7]." And the story ends.

Jaddu (secret) is a tour de force. Except for the last sentence, the entire story is in a crisp, staccato,
Hemingwayesque dialogue. There are only two characters-two sisters-and as the dialogue develops, the reader realizes that Meena has been having an affair with a young man who has promised to marry her sister Neela. The story's heart is its psychological percipience, and the spare, bone style bides a great deal of poignant nuance. The abrupt ending of the dialogues between the two sisters ends the story.

\section{Theoretical Foundation}

The studies on cohesion in English have been carrying out since six decades. The earliest work of Jacobson on poetry analyzed the syntactic structure and parallelism in the literary texts. Halliday first applied it to grammatical and lexical elements [8], and Hasan expanded it by making a detail exploration into grammatical cohesion [9]. Before the definitive work of Halliday and Hasan's Cohesion in English [10], the other researchers, such as Quirk, Greenbaum, Leech and Svartvik [11] studied cohesion and features that ground a sentence in its context, and Gutwinski [12] work focused on the stylistic application of cohesion studies.

The publication of Cohesion in English [13] can be seen as the establishment of any theory of cohesion. Halliday and Hasan state that the concept of cohesion is "a semantic one; it refers to relations of meaning that exist within the text and that define it as text" (p. 4). Halliday expanded the theory of cohesion in An Introduction of Functional Grammar [14] where he "gave up the original classification of conjunction and adopted logic-semantic relations" and he regarded substitution and ellipsis as "variants of the same type of cohesive relation" (p. 317). Hasan enlarged the concept of cohesion and divided it into structural and non-structural cohesion [15]. Further, Martin developed the system of cohesion [16] and Hoey gave the theory of lexical cohesion [17].

The theory of cohesion has been applied to different fields such as language teaching and learning, translation studies, sociolinguistics, psycholinguistics, discourse analysis, and stylistics. This theory has been proved useful to analyze a text beyond sentential. Baker applied it to translation [18] and Thompson argued that cohesion refers to "the linguistic devices by which the speaker can signal the experiential and interpersonal coherence of the text, and is thus a textual phenomenon: we can point to features of the text which serve a cohesive function" (p. 147) [19]. However, Schiffrin discussed that "cohesion has to do with semantic meaning" (p. 62) [20]. Other researchers applied cohesion to inter and intra sentence level. Martin believes that Halliday and Hasan's account "fails to bring out the continuity between the structural [...] and non-structural [...] resources" (p. 19) [21]. Some cohesionists started using different labeling for the same concept in their works, and other considered the cohesive devises in each language is different from one another. 
The study of cohesion in Hindi literacy text is a neglected area. The earlier work was done by Dwivedi in the comparative study of ellipsis in Hindi and English short stories [22]. The present paper is limited in scope as it takes into account two works from English and Hindi language. The corpus of the study is from the short stories, and it is no way author's intention to make any generalization based on the findings of these works. However, this research shows a pattern of occurrence of ellipsis in Hindi and English.

\section{Data and Discussion}

The elliptical structures in the stories are divided into three groups and I shall discuss ellipsis under three headings: nominal, verbal, and clausal. The structure of nominal group is that of a Head with optional modification; the modifier precedes or follows the Head and known as pre-modifier and post-modifier respectively. The omission of nominal group is known as nominal ellipsis. The modifier consists of deictic, numeral, epithet, classifier, and quantifier. Common noun and pronoun generally functions as a Head. The verbal ellipsis omits the verbal element. The elliptical verbal element presupposes one or more words from the previous verbal group. A verbal group whose structure fully represents its entire systemic features is not elliptical. Whenever, a verbal group is used the principal systems are: finiteness-finite or non-finite, finite-indicative or imperative, indicative-modal or non-modal, polarity-positive or negative, marked or unmarked, voice-active or passive, and tense-past, present or future. The clause includes modal (subject and finite verb) and propositional element (the remainder of the verbal group, complements or adjuncts), and the ellipsis of clause element is known as clausal ellipsis.

The occurrence of the nominal, verbal, and clausal ellipsis is located under the headings: (a) ellipsis with coordinators, such as and, or, but, and with [E1] (b) ellipsis of subject and/or, auxiliary/verb at the beginning of the sentence [E2], and (c) ellipsis when a word or expression is left out and a substitute word is sometimes put in its place [E3]. Under these headings the work to categorize elliptical elements become easy and fast, and moreover by using this method the large corpus can be categorized and analyzed conveniently.

Since the aim of this study is to help the second language learners to find out the elliptical structures in Hindi and English language, the author suggests for developing a computer software tool for finding out the structures which may be marked as elliptical at surface level, the instances of coordination, exophara and gapping are also grouped together under [E1], [E2], and [E3] respectively. The actual data of ellipsis in the stories is large therefore this paper randomly takes the first and every seventh entry from each story.

\subsection{In Hills like White Elephants Examples of [E1]}

1. The hill across the valley of Ebro were long and (were) $^{\mathrm{E} 1}$ white. (Verbal Ellipsis)

7. She put the felt pads and (she put $)^{\mathrm{E} 1}$ the beer glasses on the table and (she) ${ }^{\mathrm{E} 1}$ looked at the man and the girl. (Clausal and Nominal Ellipsis)

14. Across on the other side were fields of grain and (there $\underline{\text { were }}^{\mathrm{E} 1}$ trees along the banks of the Erbo. (Clausal Ellipsis)

21. Do you want $(\text { Anis del Toro })^{\mathrm{E} 1}$ with water? (Nominal Ellipsis)

\subsection{In Hills like White Elephants Examples of [E2]}

1. (In the area that was) ${ }^{\mathrm{E} 2}$ close against the side of the station [...] (Clausal Ellipsis)

7. (Do you want it $)^{\mathrm{E} 2}$ with water? (Clausal Ellipsis)

\subsection{In Hills like White Elephants Examples of [E3]}

1. On this side (across the valley of the Erbo) ${ }^{\mathrm{E} 3}$ there was no shade [...] (Nominal Ellipsis)

7. I've never seen one (the white elephants) ${ }^{\mathrm{E3}}$. (Nominal Ellipsis)

14. Is it (Anis del Toro) $)^{\mathrm{E} 3}$ all right. (Nominal Ellipsis)

21. I just meant the coloring of their $\underline{(t h e ~ h i l l s) ~}^{\mathrm{E} 3}$ skin through the trees. (Nominal Ellipsis)

28. Then what will do afterward (after the operation) ${ }^{\mathrm{E} 3}$. (Nominal Ellipsis)

35. If you don't want to (get operated) ${ }^{\mathrm{E} 3}$ you don't have to

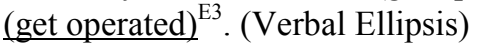

42. I'll love it (whatever you say) ${ }^{\mathrm{E} 3}$. (Clausal Ellipsis)

49. And we could have everything and every day we make it (the possibility of enjoying all the fun by avoiding the operation $^{\mathrm{E} 3}$. (Clausal Ellipsis)

56. I'm perfectly willing to go through with it (the ${\text { operation })^{\mathrm{E} 3}}$ if it (the operation $)^{\mathrm{E} 3}$ means anything to you. (Nominal Ellipsis)

63. [...] (which was) ${ }^{\mathrm{E} 3}$ made of strings of bamboo beads, (which was) $^{\mathrm{E} 3}$ hung across the open door into the bar, to keep out flies.

70. He walked through the bar room, where people (were waiting $^{\mathrm{E} 3}$ for the train were (and they) ${ }^{\mathrm{E} 3}$ drinking [...]

\subsection{In Jaadu (Trans. Secret) Examples of [E1]}

1. I don't poke my nose in yours, and (don't I) ${ }^{\mathrm{E} 1}$ know about the letters you write to your riff-raff friend every day. (Clausal Ellipsis)

\subsection{In Jaadu (Trans. Secret) Examples of [E2]}

The following text is the translation of Hindi text.

1. (You) $)^{\mathrm{E} 2}$ better know. (Nominal Ellipsis)

7. (You) ${ }^{\mathrm{E} 2}$ now became happy. (Nominal Ellipsis)

14. (Whatever you say to mother) ${ }^{\mathrm{E} 2} \mathrm{I}$ don't care. (Clausal Ellipsis)

21. Why don't (you) ${ }^{\mathrm{E} 2}$ say this? (Nominal Ellipsis)

28. Why should $\left(\underline{\mathrm{I}}^{\mathrm{E} 2}\right.$ tell what is in my heart? (Nominal Ellipsis) 


\subsection{In Jaadu (Trans. Secret) Examples of [E3]}

The following text is the translation of Hindi text.

1. Why did you write (the letter) ${ }^{\mathrm{E} 3}$ to him? (Nominal Ellipsis)

7. Never (I didn't write any letter) ${ }^{\mathrm{E} 3}$ (Clausal Ellipsis)

14. Now, how do I convince you (that I didn't smirk) ${ }^{\mathrm{E3}}$ (Clausal Ellipsis)

21. Yours side (your side I got up) ${ }^{\mathrm{E} 3}$ (Clausal Ellipsis)

28. Why are you so jealous (with me $)^{\mathrm{E} 3}$ (Nominal Ellipsis)

The following table shows the percentage of [E1], [E2], and [E3] types of ellipsis found in Hindi and English short stories:

Table 1. Comparison of ellipsis in Hindi and English short stories

\begin{tabular}{|c|c|c|c|c|}
\hline \multirow{2}{*}{$\begin{array}{c}\text { Types of } \\
\text { Ellipsis }\end{array}$} & \multicolumn{2}{|c|}{$\begin{array}{c}\text { In Hills Like White } \\
\text { Elephants }\end{array}$} & \multicolumn{2}{c|}{ In Jaadu } \\
\cline { 2 - 5 } & Number & Percentage & Number & Percentage \\
\hline [E1] & 22 & $21.15 \%$ & 5 & $7.35 \%$ \\
\hline [E2] & 11 & $10.58 \%$ & 32 & $47.06 \%$ \\
\hline [E3] & 71 & $68.27 \%$ & 31 & $45.59 \%$ \\
\hline Total & 104 & $100 \%$ & 68 & $100 \%$ \\
\hline
\end{tabular}

\section{Conclusions}

The basic concern of this study was to show the difference between the selections: we choose what to say on any given occasion but we are constrained to a large extent by the limitations of our language and the context in which we use it. Since linguistic structures are natural (and not logical), it has no meaning to question why English shows a certain type of ellipsis more and other less, or why Hindi does not work like English. It would be again erroneous to make a pattern in all SVO or SOV languages based on few literary texts, and then to generalize it further. The individual style of a writer cannot represent the entire corpus of a language. Moreover, it is restricted to a particular written corpus only.

Then the readers might question: what is the relevance of this paper? This study directs further research in this direction to understand the language as a whole. This paper suggests that computational linguists and language software developers might initiate this idea to develop a software that will demarcate [E1], [E2], and [E3] in spoken and written corpus. The paper shows that the ellipsis type [E1] and [E3] are more frequent in English than Hindi, and the ellipsis type [E2] occurs more in Hindi than English.

\section{REFERENCES}

[1] Stone, Wilfred H, Nancy H. Packer, and Robert Hoopes. The Short Story: An Introduction. New York: McGraw-Hill, 1983.

[2] Premchand, Munshi. Jaadu (Trans. Secret) f. Mansarovar. Delhi: Psutak Sansar, 1999.

[3] Halliday, M. A. K. and Hasan, R. Cohesion in English. London: Longman Publications, 1976.

[4] Halliday, M. A. K. An introduction to functional grammar. London: Edward Arnold, 1994.

[5] Gandhi, M. K. (1918). Speeches and writings of M.K. Gandhi. Madras: Natesan.

[6] Venkatesan, V. "Language Divide, A Review on Language and Politics in India." Frontline May 2009.

[7] Op. cit., Stone, 1983.

[8] Halliday, M. A. K. "The linguistic study of literary texts." Proceedings of the ninth international congress of linguistics. The Hague: Mouton, 1964. 302-307.

[9] Hasan, R. Grammatical cohesion in spoken and written English. London: Longman, 1968.

[10] Op. cit. Halliday \& Hasan, 1976.

[11] Quirk, R., Greenbaum, S., Leech, G., \& Svartvik, J. A grammar of contemporary English. London: Lonman, 1972.

[12] Gutwinski, W. Cohesion in literary texts. The Hague: Mouton, 1976.

[13] Op. cit., Halliday \& Hasan, 1976.

[14] Op. cit., Halliday, 1994.

[15] Hasan, R. "Coherence and cohesive harmony." (Ed.), J. Flood. Understanding reading comprehension: Cognition, language and the structure of prose. Newark: International Redaing Association, 1984. 181-219.

[16] Martin, J. R. English text: System and structure. Amsterdam: John Benjamins Publishing Company, 1992.

[17] Hoey, M. Patterns of lexis in text. Oxford: Oxford University Press, 1991.

[18] Baker, M. In other word: A coursebook on translation. London: Routledge, 1992.

[19] Thonpson, G. Introducing functional grammar. London: Edward Arnold, 1996.

[20] Schiffrin, D. Approaches to discourse. Oxford: Blackwell, 1994.

[21] Op. cit., Martin, 1992.

[22] Dwivedi, Amitabh Vikram. The Study of Hindi and English Ellipsis. MA Thesis. Lucknow: Author, 2004. 